\title{
EDUCATION FOR ART LIBRARIANSHIP IN ICELAND
}

Dear Editor

The ARLIS Norden group in Iceland would like to make the following remarks on Charlotte Hanner's article titled 'Education for art librarianship in the Nordic countries', published in Art Libraries Journal vol.19 no. 21994.

The title, 'Education for art librarianship in the Nordic countries', is in our opinion misleading since the author mainly described library education in Sweden.

The author describes the situation in Iceland in the following manner: 'There are no librarianship programs in Iceland'. For the sake of accuracy we feel that this misinformation needs to be corrected.

A BA program in library and information science has been offered at the Department of Social Sciences at the University of Iceland since 1964. There is a professorship in library and information science along with three assistant professors. Various other professionals teach selective courses. During the 25 year period 1964-89, 182 professional librarians have graduated from the University of Iceland. An MA program in LIS was introduced in 1993.

A selective course in art librarianship has been offered in the LIS program at the University of Iceland every two years since 1983, most recently offered during the fall semester of 1993. The following is a course description (in English) as it appears in the University of Iceland catalogue of courses:

Bókasafns- og upplysingafræedi (Library and information science)

10.01.37 Söfn listastofnana (3 credits) Art libraries

Kennari (instructor): Arndís S. Árnadóttir

An introduction to art librarianship and the world of art with the main focus on libraries in the field of fine arts (visual arts), design and decorative arts and architecture. The aims and objectives of art libraries are covered including relevant art information sources and processes intertwined with a survey in art history.

Coverage includes national and international art bibliographies, art reference work and the importance of non-book materials and visual resources. Field trips to various art institutions and museums.

Requirements:

A project (50\%) for a proposed art libary collection incl. a proposal for an exhibition. Reviews (30\%) of art bibliographies and art reference works. Reports (20\%) on current art exhibitions. Selective references.

Art library manual/Ed. by Philip Pacey. - London, New York: Bowker, 1977. Reader in art librarianship/Ed. by Philip Pacey. - München, New York, London, Paris: K. G. Saur, 1985. Jones, L. S.: Art information: research, methods and resources. - Dubuque: Kendall/Hunt, 1990.

We hope that our well meant comments will cast a new light on education for art librarianship in the Nordic countries.

Arndís S. Árnadóttir,

The Icelandic College of Art and Crafts, Auđur Sigurđardóttir,

The National Gallery of Iceland, Gróa Finnsdóttir,

The National Museum of Iceland.

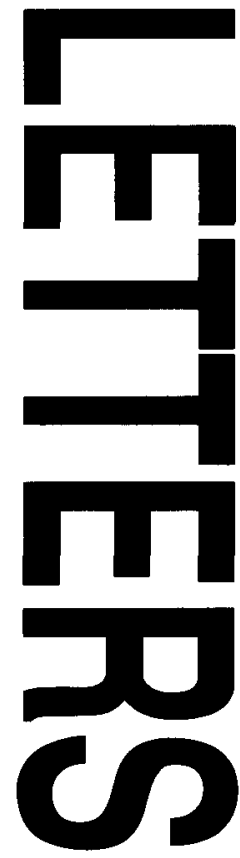

